\title{
Antifeedant Potential of Some Aromatic Plants Against Cowpea Weevil, Callosobruchus Maculatus
}

\author{
Egwunyenga Ogochukwu Andy* and Ake John Edema \\ Applied Entomology Unit, Department of Animal and Environmental Biology, Delta State University, Nigeria
}

*Corresponding author: Egwunyenga Ogochukwu Andy, Applied Entomology Unit, Department of Animal and Environmental Biology, Delta State University, Abraka, Nigeria.
Received Date: June 21, 2019

Published Date: July 01, 2019

\begin{abstract}
The antifeedant potential of extracts of five natural plants; Galic (Allium sativum), Manjack (Cordia millenii), African nutmeg (Mondora myristica), Negro pepper (Xylopia aethiopica) and Ginger (Zingiber officinale) against cowpea weevil, (Callosobruchus maculatus) was evaluated. The results established that extracts of Ginger caused the strongest feeding deterrency against the insect pests with percentage feeding index of $48.3 \%$. The order of the antifeedant potency of the extracts against C. maculatus after 5-hour exposure was Z. officinale $(43.9 \%),>\mathrm{X}$ aethiopica $(48.3 \%)>\mathrm{C}$. millenii (59.9\%) > A. sativum (61.6\%) > M. myristica (64.9\%). The study further discussed the challenges confronting researchers and farmers in practically deploying these plant materials for general use in crop protection and makes recommendations on appropriate solutions.
\end{abstract}

Keywords: Antifeedant; Plant extracts; Callosobruchus maculatus; Cowpea

\section{Introduction}

Cowpea, Vigna unguiculata is an important source of protein for millions of people in Africa and other parts of the world. Its resistance to drought, and ability to improve soil fertility and prevent erosion makes it an important economic crop in many developing countries [1]. Nigeria is the largest producer and consumer of cowpeas, accounting for $61 \%$ of production in Africa and $58 \%$ worldwide.

Cowpea production in Nigeria is greatly hampered by insect infestation both in the field and in storage. The major insect pests that can cause economic losses are aphids (Aphids craccivora), leaf hoppers (Empoasca spp), thrips (Megalurothrips sjosteclti) and the cowpea weevil (Callosobruchus maculatus) [2]. The leather beetle, C. maculatus is the most important pest of stored cowpea in Nigeria accounting for between $20-30 \%$ damage of grains, leading to economic losses to the farmers and reduction in nutritive quality. Effective methods of controlling weevils on stored cowpeas involve the use of synthetic pesticides particularly organochlorines and organophosphorus compounds. This has often led to hazardous effects on the environment, humans and development of resistance by the weevils. In addition, synthetic pesticides are not early available among poor farmers at affordable costs [3].
Farmers are now increasingly resorting to the use of local plant materials and extracts, containing rotenoids, nicotine and pyrethrum to protect stored cowpea from insect infestation. Several studies have evaluated the efficiency of many plant extracts against stored products insects [4-9]. Most of these studies examined the toxicity and repellant properties of the plant materials. There appears to be dearth of literature on the antifeedant potentials of many plant extracts on the cowpea weevil.

This study investigates the antifeedant activity of galic (Alluim sativum), maryack (Cordia millenii), nutmeg (Monodora myristica), negro pepper (Xylopia aethiopica) and ginger (Zingiber officinale) against cowpea weevil (C. maculatus).

\section{Materials and Methods}

\section{Preparation of plant powders and crude extracts}

The plant material used were Galic (Allium sativum) Maryack (Cordia millenii), African nutmeg (Mondora myristica), Negro pepper (Xylopia aethiopica) and Ginger (Zingiber officinale). They were purchased from local market in Abraka, Nigeria.

The plant materials were washed and cut into smaller sizes. They were sun dried for five days and further dried in an electric 
oven at $60^{\circ} \mathrm{C}$ for another five days [10]). The dried plant materials were pulverized separately with a sprinder and sieved through a 40 hole $/ \mathrm{mm}^{2}$ mesh to obtain fine powders. The large particles which did not pass through the mesh were regrinded and sieved to obtained additional powder. The process was repeated three times.

The crude extracts were obtained by introducing $50 \mathrm{~g}, 75 \mathrm{~g}$ and $100 \mathrm{~g}$ of the powders in $100 \mathrm{ml}$ of $95 \%$ ethanol in separate jars. The jars were regularly shaken and allowed to stand for three days. All supernatants of each plant extract were filtered and slightly heated to completely evaporate the ethanol solvent. The syrup-like crude extracts of each plant materials was stored in a refrigerator at $4^{\circ} \mathrm{C}$.

\section{Preparation Cowpea Substrate}

Uninfested cowpea seeds were purchased from the local market in Abraka and stored in the refrigerator at freezing temperature $\left(-4^{\circ}\right.$ C) for six hours to kill any living insects on the cowpea seeds. The seeds were then equilibrated to the ambient temperature of $30^{\circ} \mathrm{C}$. Only seeds considered free of infestation were used for the study.

\section{Insect Pest Culture}

Test insects, Callosobruchus maculatus were cultured using modified method of [10\&12]. Batches of heavily infested cowpeas were mixed with larger quantities of uninfested cowpea. Each mixture was distributed into seven kilner jars and covered with polyethene nets fastened around the mouth of the jars with rubber bands. Unsexed adults of the pests were used for the study.

\section{Feeding Detergency Tests}

The antifeedant activities of the five extracts on C. maculatus was determined using the filter paper feeding protection method. The tests were conducted in five sets with each preparation in replicates of three. A representative sample filter paper containing $0.5 \mathrm{~g} / \mathrm{ml}$ of each test plant was used for the feeding deterrence tests. Two control filter papers were treated one with ethanol and the other without any treatment. The filter papers were placed in labeled compartment in Petri dishes. 10 adults of C. maculatus were selected and starved for 24 hours before being introduced into the center of each compartment and allowed to feed for five days under ambient conditions. The feeding activity of the insects was recorded following methods described by Talukoler and Howse [11\}. The units are made of three conditions.

- Pure food composed of two untreated filter papers (control) (T)

- Food with possibility of choice between treated and untreated filter paper (TC) (Choice test).

- $\quad$ Food with two treated filter papers (TT) (No choice test).

Loss in weight of the filter papers was regarded as a measure of the amount of food consumed. The percentage feeding index (PEI) was calculated using the method employed by [13].

All experimental data obtained were analyzed by Analysis of Variance (ANOVA) to compare the antifeeding properties of the five plant materials.

\section{Results}

The feeding deterrence of the plant extracts on cowpea weevil, Callobruchus maculatus over five hours exposure period is summarized in Table 1. The result established that the extracts of ginger (Z. officinale) caused the strongest feeding deterrence against the insect pest, C. maculatus with percentage feeding index (PFI) of 43.9. The next most powerful antifeedant against $C$. maculatus was negro pepper (X aethuipica), galic (A. sativum), and African nutmeg (M. myristica) with PFI of 59.9, 61.6 and 64.9 respectively. Thus, the order of antifeedant potency of the extracts against C. maculatus was Z. officinale (43.9\%) > X aethiopica (48.3\%) C millenii (59.9\%) > A. sativum (61.6\%) > M myristica (64.9\%).

\footnotetext{
11
}

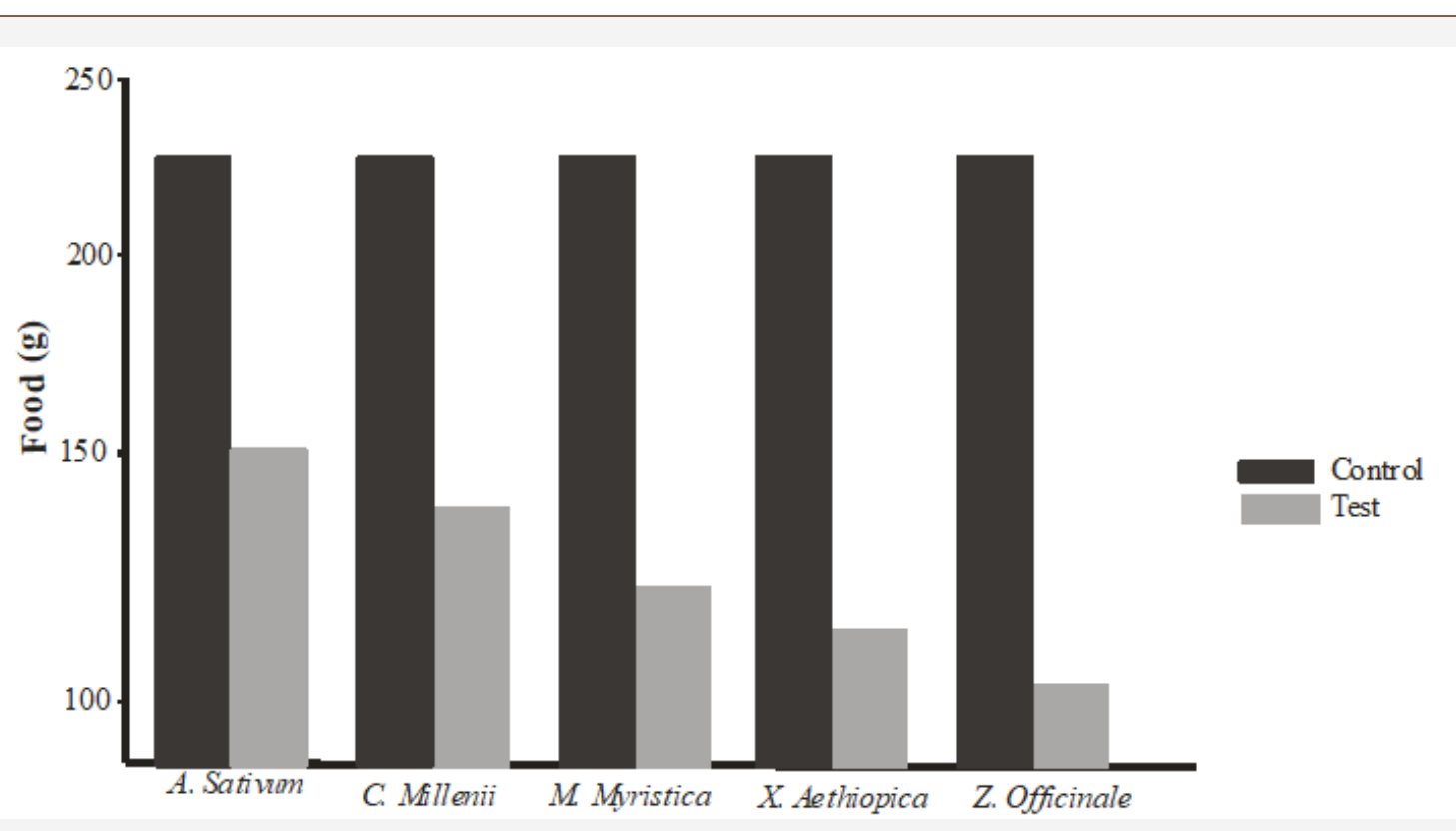

Figure 1:Shows the quantity of Food consumed by T.castaneum in control and test over 5 hours. 
Table 1: Antifeedant Activities of Plant Extracts Against Triboolium Tribolium castaneum Over 5 Hours.

\begin{tabular}{|c|c|c|c|c|c|c|}
\hline \multirow{2}{*}{ Plants Insects } & \multirow{2}{*}{ Plant Part Used } & \multicolumn{2}{|c|}{ Food Presented (mg) } & \multicolumn{2}{|c|}{ Food Consumed } & \multirow{2}{*}{ PFI } \\
\cline { 3 - 7 } & & Control & Test & Control & 151.5 & 207 \\
\hline C. sativum & Bulb & 500 & 506 & 230.6 & 140.7 & 24.2 \\
\hline C. millenii & Seed & 500 & 506 & 230.6 & 118.5. & 32.1 \\
\hline M. myristica & Seed & 500 & 506 & 230.6 & 110.8 & 35.1 \\
\hline Z. officinale & Rhizome & 500 & 506 & 230.6 & 96.5 & 40.9 \\
\hline X. aethiopica & Fruit & 500 & 506 & 230.6 & & \\
\hline
\end{tabular}

C. sativum > C. millenii $>$ M. myristica $>$ Z. officinale $>$ X. aethiopica

The amount of food consumed by $\mathrm{C}$ maculatus during the 5hours exposure to the plant extracts is further illustrated in Figure 1. It showed that the differences in the percentage feedings index (PFI) of C. maculatus due to extract over 5 hours exposure were not statistically significant $(\mathrm{P}<0.05)$.

\section{Discussion}

Feeding deterrents are behavior modifying secondary metabolite in plants that act directly on peripheral taste organs of phytophagous insects thereby preventing them from feeding or ovipositing [14]. Antifeedant properties are found in the major classes of secondary metabolites like alkaloids, phenolics and terpenoids [15], some of which particularly terpenoids, have been identified in the plants used for this study [16].

The results of this study are similar to findings by various workers who demonstrated feeding deterrence of some botanical extracts against insects in the field and laboratory trials. [17] used nutmeg (M. myristica) oil to deter food consumption by rice weevil Sitophulu zeamais and the red flour beetle, Tribolium castaneum. Various studies [18-22] have reported that botanicals and certain medicinal plants essential oils possess antifeedant properties many important stored product insects. The findings of this study agree with them and further highlights the antifeedant effects of Z. officinale, C. millenii and X. aethiopica which had been previously unreported as antifeedant against cowpea weevil. The difference in the pest responses or the intensity of the feeding deterrence by the plants could be due to concentration differences of the active principles of the extracts.

The five plant extracts used in this study have all shown clear potentials to protect cowpea seeds in storage against attack and damage by C. maculatus. In spite of this, various challenges confronting researchers and farmers in practically deploying the plant extracts for general use abound. [23] identified some of these challenges to be the non-availability of these potent plant's materials in commercial quantity to farmers to replace the synthetic pesticides. The other challenges are production problems, as well as distribution and marketing of plant-based pesticides. This therefore emphasizes the need to establish appropriate supply chains that share the benefits of these potential plant insecticides with the local communities from which they are harvested [24].

The five plant materials used in this study, Ginger, Manjack, Galic, Negro Pepper and African nutmeg are spices which are edible and serve culinary purpose in Nigeria and many other countries in Africa. Thus, their application for protection of cowpeas is recommended because they are edible, economically viable and environmentally safe. In addition, the plant materials and extract did not affect the appearance, flavor, texture and overall acceptability of the treated cowpea seeds.

\section{Acknowledgement}

None.

\section{Conflict of Interest}

No conflict of interest.

\section{References}

1. IITA (2018) Cowpea (Vigna maguiculata) International Institute for Tropical Agriculture (IITA)

2. Tirosesele B, Thomas K, Sekeleme S (2015) Control of Cowpea Weevil, Callosobruchus maculatus (Coleoptera, Bruchidae), Using Natural Plant Products. Insects 6(1): 77-84.

3. Reuben OS, Minza M Rhodes M, Malungu L (2006) Control of Cowpea Weevil (Callosobruchus maculatus L.) in stored cowpea (Vigna unguiculata) Grains using Botanicals. Asian Journal of Plant Sciences 5(1): 91-97.

4. Yusuf AU, Die MC, Adebitan SA, Ahmed BI (2011) Comparative efficacy of seven plant products on the cowpea bruchid, Callosobruchus maculatus. Journal of Biopesticides 4(1): 19-26.

5. Egwunyenga OA, Nmorsi OPG, Dibie C (1997) Repellent Effects of Capsicum sf and Aframemum melagueta (K) (Anonaceae) to callosobruchus maculatus (F). (Coleoplera: bruchidae) Bulletin of Science Association of Nigeria 21: 163-166

6. Egwunyenga OA, Nmorsi OPG, Alo EB (2000) Repellency of Two Pepper Varieties to Cowpea weevil, Callosobruchus maculatus. Nigeria Journal of Science and Environment 2: 69-73.

7. Danjuma BJ, Majeed SB, Manga A, Yayaha MC, Dike A, Bamayi L (2009) Effect of some Plant Powders in the control of Sitophilus zeamais Motsh (celeoptera), 4(4): 313-316.

8. Denloye AAB, Makanjuola WA (2001) Evaluation of the Crude Aqueous Extracts of onion (Alluim cefa) and Galic (Allium sativum) for the control of Cowpea and Maize weevils. Journal of Prospect and Science 1: 58-62.

9. Denloye AA, Makanjuola WA, Babalola 00 (2003) Toxicity and Repellent Effects of Crude Aqueous Extract of Garlic (Allium sativum) on larva and Adult mosquitoes. African Entomology 11(2): 287-290.

10. Sowunmi EO (1983) Effect of Storage Length and insecticidal treatment on Cowpea (Vigna unguiculata). Tropical Legume Bulletin 27: 21-27.

11. Talukder FA, Howse PE (1995) Evaluation of Aphanamixis polystachya as a source of repellents, antifeedants, toxicants and protectants in storage against Tribolium castaneum (Herbst). Journal of Stored Products Research 31(1): 55-61.

12. Don Pedro KN (1985) Toxicity of some citrus Peels to Dermestes maculatus (Deg) and Callosobruchus maculatus (F). Journal of Stored Products Research 21(1): 31-34. 
13. Isman MB, Koul O, Luczynski A, Kaminski J (1990) Insectical and antifeedant bioactivities of neem oil and (their relationships to azadirachten content) Journal of Agricultural Food Chemistry 38: 14061411.

14. Isman MB, Matsuura H, Mackinnon S, Durst T, Towers GHN, et al. (1996) Phytochemistry of the Meliaceae. So Many terpenoids, so few insecticides. Recent Advances in Phytochemistry 30: 155-178.

15. David BV, Ananthakrishna TN (2004) General and Applied Entomology. 2nd edition. Tata McGraw Hill Education Private Limited, 1184 pp.

16. Ake JEG (2011) Repellent, Insecticidal and Antifeedant Potential of Selected Aromatic Plants Against Three Storage Insect Pest. PhD Thesis (Unpublished). Department of Animal and Environmental Biology, Delta State University, Abraka, Nigeria.

17. Huanga Y, Tana JML, Kinib RM, Hao SH (1997) Toxic and Antifeedant Action of Nutmeg oil against Tribolium castaneum. (Herbst) and Sitophilus oryzea (Motsch). Journal of Stored Products Research 33: 289-298.

18. Huanga Y, Lay SL, Ho SB (2000) Bioactivities of essential oil from Ellectaria cardamomum (L) Mantom to Sitophilus zeamais (Motschulsky) and Tribolium castaneum (Herbst). Journal of Stored Products Research 36: 107-117.

19. Duraipanduyan V, Ignacimerthus S, Paulrag MG (2011) Antifeedant and Larvicidal activities of Rhein Isolated from the Flowers of Gassia fistula L. Saudi Journal of Biological Sciences 18(2): 129-133.
20. Elumalau K, Krishnappa K, Anandan A, Govindaranjan M, Mathivanan T (2010) Antifeedant Activity of Medicinal Plant Essential Oils Against Spodoptera litura (Lepidoptera: Noctuidae). International Journal of Recent Science Research 2: 2-68.

21. Jeyasankar A, Raja N, Ignacimuthu S (2010) Antifeedant and growth inhibitory activities of Syzgtian lineare Wall (Myrtaceae) against Spodoptera litura Fab (coleopteran: noctuidae). Current Research Journal of Biological Science 2(3): 173-177.

22. Kumarai GNK, Balachandran J, Aravind S, Ganesh MR (2003) Antifeedant and growth inhibitory effects of some neo-clerodane diterpenoids isolated from Clerodendron species (Verbenaceae) on Earias vitella and Spodopetra litura. Journal of Agricultural Food Chemistry 51: 15551559.

23. Arora S, Mogha N, Bharadwaj T, Srivastava C (2016) Anitfeedant and Insecticidal Activity of Plant Extracts Against Spodoptera litura (Fab) and Lipaphis erysimi. Proceedings of the National Academic of Sciences. Section 13: Biological Sciences.

24. Grzywacz D, Stevenson PC, Mushobozi WL, Belmain S, Wilson K (2014) The use of indigenous ecological resources for pest control in Africa. Food Security 6(1): 71-86. 